is in fact carried out in industry. These figures take account of the reduction in Federal research funds voted by Congress last month (Nature, 216, 1155; 1967).

Analysis of 1968 expenditure shows a relative shift to the social sciences in the distribution of Federal research funds. For the first time since figures became available, the increase in Federal spending in this sector will be greater than the increase in the physical sciences. Rescarch into social problems is a dominant factor in the programmes administered by the Department of Health, Education and Welfare (HEW), the Department of Housing and Urban Development (HUD), the Department of Labor and the Office of Economic Opportunity (OEO). The 1968 fiscal year budgets for these departments are 220 per cent higher than those for comparable programmes in 1961. In contrast the spending on research and development by the Department of Defense, NASA and AEC has increased by only 73 per cent during this period, most of which is a result of the substantial rise in space expenditure. Nevertheless, these three agencies will receive 86 per cent of Federal research funds in 1968, as distinet from their 91 per cent share in 1961 .

In the decade 1955-65, research and development expenditure grew at an annual rate of 14 per cent, against an annual growth rate of 5.5 per cent in gross national product. The Battelle Institute feels that this runaway rate of growth has now been contained and will remain so for the foreseeable future. Henceforth research and development is likely to grow at about the same rate as the GNP. Budget administrators in other countries who have watched with alarm the importunate demands of science research will take cheer from the modus vivendi now apparently reached in the United States. Scientists may feel differently.

\section{Teaching Aids in Sussex}

A GRANT of $£ 10,000$ has been awarded by the Depart. ment of Education and Science to the Centre for Academic Services at the University of Sussex to assist a co-operative project for the development and application of educational technology at all levels of education in the region. The centre at Sussex is one of the ten which were selected by the University Grants Committee to develop audio-visual aids in education. It was founded in February 1966 with the help of a grant from the Rank Organization.

This particular study will be carried out in associa. tion with the Nuffield Resources for Learning Project and the five local education authorities of East Sussex, West Sussex, Brighton, Eastbourne and Hastings. The objective is to analyse the existing audio-visual resources in schools and to estimate the potential for educational technology in the area. Regional co-operation in developing new methods and equipment will be considered and the costs and possible effects of such developments will be analysed. The proposals for joint activity include programmed learning, radio, closed circuit and broadcast television, language laboratories and film and projection systems.

A policy committee has been set up by the university to advise on the project and includes the five chief education officers of Sussex, Mr R. H. Adams (divisional inspector of schools for the south-east of
England), Mr Tim McMullen (co-ordinating director of the Nuffield Resources for Learning Project), Professor G. Allen (sub-dean of the University School of Educational Studies), and $\mathrm{Mr}$ Norman Mackenzie and $\mathrm{Mr}$ Hywel C. Jones (director and deputy director of the Centre for Academic Services); the university will act as co-ordinator for the scheme. The project was started on November 1, 1967, and is expected to last for two or three years.

What is interesting about the scheme is that it involves the getting together of five local education authorities with the university, to their mutual advantage. According to Mr Norman Mackenzie, although the operation is a modest one it will at least show how advantageous such co-operation can be.

\section{Training Computer Users}

THe Government and industry are well aware of the need for trained computer manpower and of the shortage of suitable training courses for such personnel. To help satisfy this demand, the British Computer Society is introducing professional qualifications this year. And training courses for computer users, particularly those on the professional and managerial side, are also important. It is therefore welcome that new and extended computer courses are being made available, from the end of January, to people in just this group by Rolls-Royce Ltd.

Rolls-Royce has for many years organized a wide range of courses of various levels in computing and data processing for its own staff. The Ministry of Technology seems to have suggested that the firm's courses should be extended to people from other firms. The suggestion was accepted and the courses now offered have been designed to make them acceptable to people from a broad range of other organizations.

Five-day residential courses in computer systems in management design, research and development will be held in Nottingham at a cost of 150 guineas each (one guinea $=£ 1 \cdot 05$ ). One-day appreciation courses for executives for $\mathbf{2 5}$ guineas will be held in Manchester and London. Four-week courses in systems analysis and design will be held in Largs, Stratford upon Avon, Derby and Droitwich. In addition there will be three short courses for directors of firms with a turnover of $£ 50$ million and above. The value of these new courses may lie in the wide experience of Rolls-Royce in specific applications of computers.

\section{New Look Laboratories}

THE 39th Building Bulletin of the Department of Education and Science (HMSO, 13s. 6d.) deals with the design of a science block for a large boys' grammar school. The block was designed for the Oxford School - a new school formed by the merger of the oldestablished City of Oxford High School and the prewar Southfields School. Four architects and a quantity surveyor of the Development Group of the Architects and Building Branch at the ministry worked on the project in collaboration with the Oxford local authority. Two consulting firms were called in to advise on heating and electrical work, and the school was built in just over a year and a half.

The importance of science in the curriculum seems to have been fully appreciated from the beginning, 
partly on the basis of the 1961 policy statements of the Science Masters' Association (SMA) and the Association of Women Science Teachers (AWST) (now merged into the Association for Science Education). Accommodation in the Oxford School was therefore provided for each of the three stages of science education in secondary schools described by the SMA and the AWST statements-two years of general science teaching in the introductory phase, three years of intermediate work leading to o-level and two or three years of advanced work. The Oxford School has a four form entry, and a total of about 800 boys. Allowance was made for six teaching periods a week of science in the introductory phase, three to four periods for each of chemistry, physies and biology in the middle school and seven periods for each of the three subjects in the sixth form. The proportion of time allotted to science under this scheme is higher than in most other schools, with the result that the science block is larger than is usual. Twenty-four boys per class was thought to be the best number for middle school science, so that flexibility can be maintained in the timetable, while fifteen was considered the optimum number for experimental work in the advanced stage. Mathematics classrooms have added to the size of the block.

Self-contained subject departments were provided for the school, following the wishes of the staff, but the bulletin suggests that better use might have been made of space if closer integration had been considered, particularly as the boundaries between science subjects are becoming more blurred. Stores and preparation rooms for different subjects which often provide similar facilities and apparatus could well be shared by laboratories of different disciplines. The design of the separate departments is described in detail in the bulletin.

As well as educational questions the group had definite technical objectives in view. The first was to test a dimensional control system proposed by Dr J. W. Harding of the Building Research Station in his paper "Co-ordination by Design Modules". The second was to develop a rapidly erected "dry" form of construction that can be used for a variety of ten-storey buildings. Further use of the lighting system PSALI (permanent supplementary artificial lighting of interiors), first applied by the group to rooms at Harris College, Preston, was the third objective. This system is designed to provide strong light during the day to compensate for lack of daylight, but at night provides a lower level of light throughout the room. The fourth intention of the group was to gain experience with a computer for processing the bill of quantities, and apply modern management techniques, such as network analysis, to the scheme.

The project was under way before even the preliminary conclusions of the Nuffield Science Teaching Project were published, and the bulletin admits that the Oxford block may not be the best answer for the Nuffield requirements, but the detail and ideas put forward in the bulletin will be of considerable value to those designing science buildings in schools.

\section{Advice from Harwell}

DESPTTE the admonitions of the Select Committee on Science and Technology, Harwell continues to diversify.
This time it will be lending its experience to engineering companies involved in the problems of heat transfer and fluid flow. In return for an annual fee of about $£ 1,000$, firms will receive reports on the design of equipment, and there will also be a consultation service available to individual firms. The Chemical Engineering and Process Division has for the last ten years been working on heat transfer and fluid flow in the design of nuclear plants, and has therefore come into repeated contact with many of the firms that have shown interest in the new service. As early as 1954, for example, APV collaborated with Harwell on the flow of thorium bismuthide through pipes. This history of co-operation doubtless explains the enthusiasm felt in industry for the new service. The Atomic Energy Authority has announced that there will be long-term support programmes of research into problems chosen in consultation with industry.

Perhaps about 10 per cent of Harwell's scientists are now engaged on projects which could be described, in the words of the select committee, as "not inextricably linked to the primary task" of the Atomic Energy Authority. Finding ways of filling in the spare time of vast nuclear establishments is not merely a British pastime. At Oak Ridge Laboratory, in the United States, for example, there are teams working on desalination and centrifuges for medical use, both areas already tackled at Harwell.

\section{Britain Sick}

Among the winter "epidemics" which have recently been spreading through Britain, influenza at least seems to be on the decline. But bronchial complications associated with the infection are still increasing and the red warning for extra available hospital beds is still on.

The virus which has been causing this latest outbreak is influenza virus $A 2$, which is very similar to that responsible for the pandemic in 1957 and for several outbreaks since then. Of the three types of influenza virus, $A, B$ and $C$, type $A$ is the most common cause of influenza in humans and is associated with the pandemics and serious epidemics, while type $B$ is usually associated with small outbreaks which are rarely extensive; type $C$ usually causes inapparent infections. Because the virus is not a new sub-type, it is thought that most people will have acquired immunity to infection, and that the existing vaccines which consist of recent strains of $A 2$ are likely to afford protection. The principal danger arises when one sub-type mutates to another as in the pandemies of 1891, 1918 and 1957 and the serious epidemics of 1946. The periodicity of outbreaks on a less extensive scale is usually related to the accumulation of susceptible individuals and the removal of immune ones by death.

Another RNA virus-respiratory syncytial (chimpanzee coryza agent)--has been identified as the cause of death of five infants in Walsall and two more infants have recently been admitted to hospital with the same infection. This virus, which usually causes minor respiratory infections in adults, may, however, be associated with bronchitis and broncho-pneumonia in children and is very widespread-infecting children within the first few months after birth. Furthermore, antibodies present in the serum do not always prevent 